Historic, archived document

Do not assume content reflects current scientific knowledge, policies, or practices. 



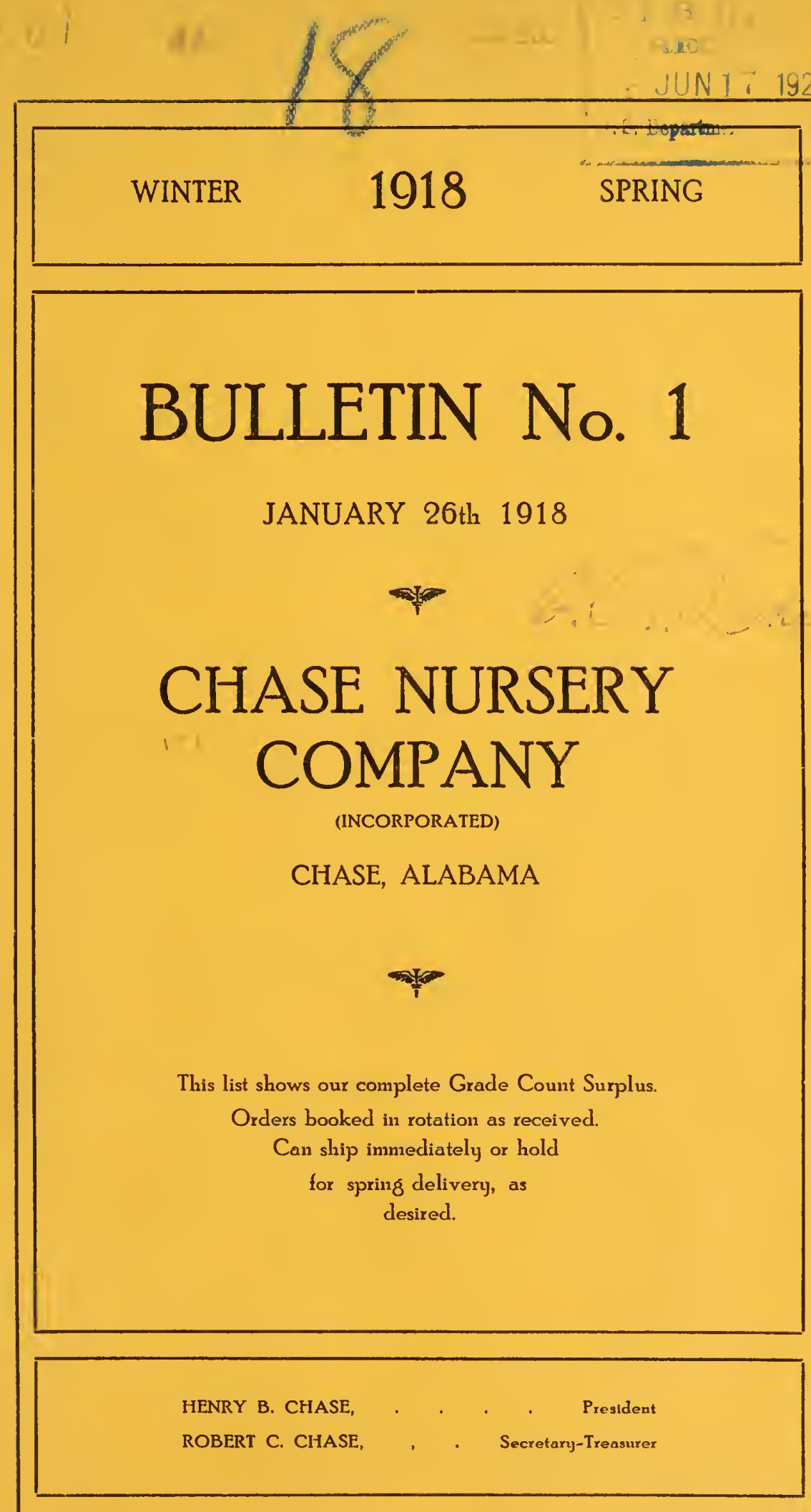




\section{TERMS AND CONDITIONS}

TERMS

All Invoices payalle net 60 days from date to customers of known responsibility.

Cash before shipment is required from parties unknown to us, or references with sufficient time for investigation before shipment.

All prices are for goods in Nursery, Packing Extra (except on Seedlings, etc., as noted).

No claims for rejections or deficiencies will be entertained unless made within five days after arrival of goods.

\section{SHIPMENTS}

Please state how you want your shipments made, whether by freight or express; also route. Where no instructions are given, we will ship as we think best serves your interests without assuming respolisibility.

THE RISK AND COST OF TRANSPORTATION BELONG TO PURCHASER.

\section{PRICES}

We quote prices per 10 , per 100 , and per 1,000 , as our stock warrants, and will supply nurserymen and dealers at prices named regardless of the size of the order, except in cases of long assorted lists of small quantities, when an additional charge will be made to cover the extra labor involved. PRICES ARE SUBJECT TO MARKET CHANGES.

\section{REFERENCES}

As to our standing and responsibility we refer you to any bank or business house in Huntsville, Alabama, the Commercial Agencies and the leading nurserymen of the United States.

\section{SPECIAL NOTICE}

This list is intended for the TRADE ONLY. If it reaches people NOT ENTITLED to Trade prices, we will thank any Nurseryman or Florist to advise us, so that our mailing list may be corrected.

We do not employ agents. We do not pack dealers' orders on our grounds, and do not authorize dealers to use our name.

\section{BUNCHING}

Fruit Trees, 1 to 2, 2 to 3 , and 3 to 4 feet, are tied 25 to the bunch; all larger grades, 10 to the bunch. Please make your orders in multiples of these quantities. 
Albemarle Pippin

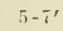

Ben Davis

Delicious

Ea. Harvest

Fall Pippin

Gano

Grimes Golden

Hacliworti

Horse

Jonathan

Kinnard's Choice

MeIntosh

IIam Blacktwig

Rome Beauty

Red Astrachan

Red June

Rosbury Russett

Sweet Bough

Transcendent

Stayman

Winesap

York Imperial

Yates

Yel. Transparent

Two upper grades tied in bundles of $10 ; 3$ to $4 \mathrm{ft}$. and smaller tied in bundles of 25. Please make your orders in multiples of these numbers.

\section{AIRICOT - 1 Year on Peach}

5 to $7 \mathrm{ft} ., 3 / 4$ to 1 inch, well branched

code

4 to $6 \mathrm{ft} ., 9 / 16$ to $5 / 8$, well branched.

ADD

4 to $5 \mathrm{ft}$., $1 / 2$ to $9 / 16$, branched

A DMIT

4 to $6 \mathrm{ft}$., whips, caliper, about $1 / 2$ inch

ADDICT

ADORE

3 to $4 \mathrm{ft}$., mostly whips.

ADAPT

2 to $3 \mathrm{ft}$., whips

ADAGE

Alexander

Budd

Ea. Golden

Royal

IVilson

$\begin{array}{ccc}3 / 4-1 " & 9-16-5 / 8 & 1,2-9-16 \\ \cdots & \cdots \ldots . . & 40 \\ 40 & \cdots \ldots . . & 124 \\ \ldots \ldots & 20 & \ldots \ldots \ldots \\ 130 & 45 & 34\end{array}$

$4-6 j^{\prime}$

90

180

180

30

60
Per 100

$\$ 17.50$

15.00

12.50

10.00

8.00

6.00

$2-3^{\prime}$

18

10

\section{VHCTARINAS-1 Year on Peach}

5 to $7 \mathrm{ft}$, well branched

4 to $5 \mathrm{ft}$., well branched.

3 to 4 it., lightly branched

2 to $3 \mathrm{ft}$., mostly whips

1 to $2 \mathrm{ft}$., whips.

New White

Red Roman

$3 \mathrm{ft}$ and $\mathrm{up} \mathrm{tied} \mathrm{in} \mathrm{bundles} \mathrm{of} 10$;
NECK

NECTAK

NEDDLE

NEEDY

NEIGH

22 $3-4^{\prime}$

35
$\$ 15.00$

12.50

10.00

8.00

5.00

$1-2^{\prime}$

240

Please

order accordingly. 
CHERRY - Two Year on Mahaleb

5 to $7 \mathrm{ft}$, $3 / 4$ to 1 , well branched

4 to $6 \mathrm{ft}$, $5 / 8$ to $3 / 4$, well branched

4 to $5 \mathrm{ft}$., $1 / 2$ to $5 / 8$, branched

$\mathrm{CAB}$

$3 / 4$ to $1 " 5 \%$ to $3 / 4$

Black Tartarian

Early Richmond

English Morello

Gov. Wood

Lambert

Montmorenci

Mercer

Olivet

Ostheime

Napoleon

Rockport

Schmidt's Big.

Windsor

Yel. Spanish

SWEET CHERIS - 1 Year Whips
CABLE

CAD

Per 1,000

$\$ 175.00$

135.00

110.00

$1 / 2$ to $5 / 8$

800

$370 \quad 1125$

145

78

385

48

72

240

25

540

250

100

Per 100

$\$ 15.00$

13.00

12.00

10.00

2103,

64

50

Gov. Wood 190

Napoleon

CHEIRR - 1 to 2 Feet

These are smooth and well rooted, price per thousand.
90 Black Tartarian.
$400 \%$ Early Richmond.

58 Gov. Wood.

75. May Duke.

200 Montmorenci.

525 Napoleon.

$140^{2}$ Saylor.

115 Yel. Glass.

200 Yel. Spanish.

COMPASs CHERIR - 1 Year on Americana Plum

CODE

CANTER

Per 100

286 Compass, 3 to $4 \mathrm{ft}$

\section{MULBERIRY}

$\$ 10.00$

135 Abundance, 2 to $3 \mathrm{ft}$.

Per 100

$\$ 10.00$

330 Downing, 2 to $3 \mathrm{ft}$

10.00

50 Multicaulus, 4 to $5 \mathrm{ft}$.

15.00

100 Multicaulus, 3 to $4 \mathrm{ft}$.

12.50

50 Multicaulus, 2 to $3 \mathrm{ft}$.

8.00

FI(AS-Two Year

Cellared early, sound to the tips.

4 to $5 \mathrm{ft}$

3 to $4 \mathrm{ft}$.

FABIE

Per 100

2 to $3 \mathrm{ft}$.

FACE

$\$ 30.00$

FACT

18 to 24 -inch

FATE

12 to 18-inch

FALIT

25.00
20.00

15.00

10.00

Black lschia

$4-5 \quad 3-4^{\prime}$

$2-3, \quad 18-2$

$12-1 \times n$

Blue Geona

15

10

132

30

40

Magnolia

White Adriatic

35

20

50

100

200

Figs, 4 to $5 \mathrm{ft}$, tied in $5 \mathrm{~s}, 3$ to $4 \mathrm{ft}, 2$ to $3 \mathrm{ft}$ tied in $10 \mathrm{~s}$, smaller grades in

25s. Please order accordingly.

IBUNCHING-Fruit trees 1 to 2,2 to 3 and 3 to 4 feet tied 25 to the bunch. All larger grades 10 to the bunch. Please make your orders in multiples of these quantities.

Shall we substitute on either variety or grade if sold out of any item you order? 
5 to $7 \mathrm{ft}, 3 / 4$ to $1-\mathrm{in}$., well branched

5 to $6 \mathrm{ft}$., $5 / 8$ to $3 / 4$-in., well branched.

4 to $5 \mathrm{ft}$., $1 / 2$ to $5 / 8-i n$., well branched.

Abundance

Burbank

Bradshaw

Grand Duke.

Green Gage

German Prune

Lombard

Moore's Arctic

Pond Seedling

Red June

Shippers Pride

Reine Claude

Shrop. Damson

wickson
Per 1,000

PLAGUE

PLAID

PLAIN

$3 / 4$ to $1^{\prime \prime}$

$\begin{array}{rrr}\ldots . & 450 & 420 \\ \ldots . & 680 & 380 \\ \ldots . & 150 & 18 \\ 98 & 104 & \ldots \ldots . \\ 10 & 32 & \ldots \ldots \\ 260 & 850 & 60 \\ \ldots . & 600 & 250 \\ 150 & 160 & \ldots \ldots \ldots \\ 110 & 16 & \ldots \ldots . \\ \ldots . & 470 & 500 \\ \ldots . & 45 & \ldots \ldots \\ \ldots . & 30 & 17 \\ 140 & 500 & 100 \\ \ldots . & 15 & 40\end{array}$

\section{PHACH-1 Year}

$\$ 160.00$

135.00

110.00

to to $5 / 8$

420

80

8

60

250

500

17

40

4 to $6 \mathrm{ft}$., $9 / 19$ to $5 / 8$, well branched

PEAL

PEA'T

3 to $4 \mathrm{ft}$., $7 / 16$ to $1 / 2$, branched

3 io $4 \mathrm{ft}$., under $7-16$, mostly branched

PECK

PEEP

2 to $3 \mathrm{ft}$., whips and branched.

PEG

2 to $3 \mathrm{ft}$., whips and branched.

PEG

1 to $2 \mathrm{ft}$, mostly whips.

PELF

A.lcxander

Belle of Georgia

Crowtord Early

Crawford Late

Carman

20
168

$4-16-3 / 8 \quad 1=-9-16$

$i-16 i-i_{2}$

$3-4^{\prime}$

$\underline{2}-3$

Per 1,000

$\$ 80.00$

70.00

70.00

50.00

40.00

40.00

25.00

1-2'

75

142

21

300

Connecticut

Champion

$168 \quad 550$

Chinese Cling

('rosby

… $\quad 76$

94

Early Rivers

Francis

$\begin{array}{lr}\cdots . & 94 \\ \cdots . & \end{array}$

630

475

325

217

442

800

450

64

325

339

50

50

1050

Early Elberta

r'itzgerald

$100 \quad 350$

423

110

.........

97

222

260

37
106

18

50

325

12

F. St. John

Fosier

Fox Seedling

Irreenstioro

20

7

…....

.......

153

254

$77 \quad 223$

165

150

520

313

148

303

$\begin{array}{lll}470) & 187 & 187\end{array}$

526

510

275

230

Globe

Gold Drop

Heath Cling

Hale

Iron Nountain

II ayfower

Mrcollister

Niagara

(a)

…....

$\ldots+\ldots$

O. M. Free

Rochester

Stump

Triumph.

80
238
$\ldots .$.
50
5

25

74

125

200

25

125

800

40

Three upper grades are tied in to a bundle, three lower grades are tied 25 to the bundle. Please make your orders accordingly. 


\begin{tabular}{|c|c|c|c|c|}
\hline \multirow{6}{*}{ 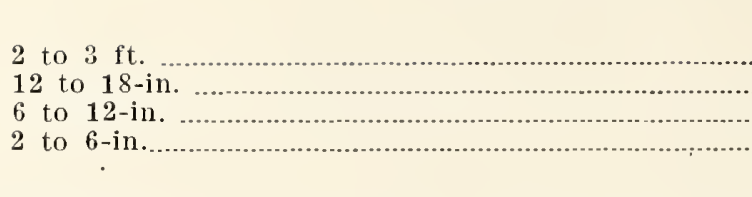 } & \multicolumn{4}{|c|}{ Per 1,000} \\
\hline & \multicolumn{3}{|c|}{ PIE } & $\$ 50.00$ \\
\hline & \multicolumn{3}{|c|}{ PILL } & 35.00 \\
\hline & \multicolumn{3}{|c|}{ PILOT } & 25.00 \\
\hline & \multicolumn{3}{|c|}{ PINE } & 20.00 \\
\hline & $2-3^{\prime}$ & 12 to $1 s^{\prime \prime}$ & 6 to 12 " & 2 to $6 " 1$ \\
\hline Carman .... & 550 & & & \\
\hline Gov. Hogg & $\ldots .$. & 1300 & 650 & 150 \\
\hline Gordon ........ & $\ldots$. & 3225 & 1475 & 650 \\
\hline 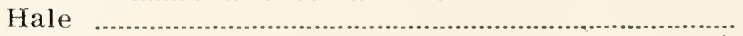 & & 300 & .......... & \\
\hline Mayflower & 575 & 1225 & & \\
\hline
\end{tabular}

\section{QUNCE-Two Year}

4 to $5 \mathrm{ft} ., 9 / 16$ to $5 / 8$, well branched

Per 100

3 to $4 \mathrm{ft}$., $1 / 2$ to $9 / 16$, well branched

3 to $4 \mathrm{ft}$., under $1 / 2$, branched

2 to 3 ft., branched.

QUACK

QUAFF

$\$ 17.50$

15.00

QUAIL $\quad 12.50$

10.00

QUAKE

$9-16-5 / 8 \quad 1 / 2-9-16 \quad 3-4^{\prime}$

$2-3{ }^{\prime}$

Borgeat

20

under 1/2"

Champion

Orange

Reas Mammoth

70
$\cdots$

200

\section{I'FAR-Two Year, Budded on French Jopu Roots}

6 to $8 \mathrm{ft} ., 3 / 4$ to 1 -in., well branched

5 to $7 \mathrm{ft}$., $5 / 8$ to $3 / 1$-in., well branched

2 to $3 \mathrm{ft}$., whips

1 to $2 \mathrm{ft}$.

Bartlett

Buerre de Anjou

Clapps Favorite

Duchess

Flemish Beauty

Early Harvest

Garber

Howell

Japan Golden Russett.

Koonce

Kieffer

LeConte

Magnolia

Seckel

Wilder The 2 to $3 \mathrm{ft}$. and 1 to $2 \mathrm{ft}$. were cut back last spring, good smooth stock,
suitable for mailing or lining out. Light grades tied in bundles of 25 , heavy grades tied in bundles of 10 . Please make orders in multiples accordingly.

\section{DUARF PEAR}

380 Duchess, $1 / 2$ to $5 / 8$, well balanced

PASTE

Per 100 $\$ 8.00$

\section{JAPANESE P'RREIMMON}

125 Assorted, named varieties, 3 to 4 ft.

Per 100

$\$ 15.00$ 10.00

\section{I'ONEGRAVATE}




\section{Seedlings, Hxcept as Noted}

Al.MOND, Soft Shell, Budded on Peach,

Per 100

4 to $5 \mathrm{ft}$., well branched

$\$ 20.00$

3 to $4 \mathrm{ft}$., well branched

15.00

2 to $3 \mathrm{ft}$., branched

10.00

1 to $2 \mathrm{ft}$., mostly whips

see varieties and count below.

I. X. I.

$\begin{array}{ccc}4 \text { to } 5 & 3 \text { to } 4^{\prime} & 2 \text { to } 5 \\ 70 & 107 & 175 \\ 20 & 200 & 235\end{array}$

1 tก $2^{\prime}$

115

Ne Plus Ultra

145

Per 100

$\$ 50.00$

40.00

50 Chestnut, Japan Mammoth, 4 to $5 \mathrm{ft}$., well branched

30.00

25 Chestnut, Japan Mammoth, 3 to $4 \mathrm{ft}$., well branched

25.00

25 Chestnut, Japan Mammoth, 2 to $3 \mathrm{ft}$, well branched

35.00

350 Chestnut, Spanish, 6 to $8 \mathrm{ft}$, well branched

30.00

600 Chestnut, Spanish, 5 to $6 \mathrm{ft}$., well branched.

20.00

300 Chestnut, Spanish, 4 to $5 \mathrm{ft}$, well branched.

15.00

250 Chestnut, Spanish, 3 to $4 \mathrm{ft}$., branched

50.00

300 Pecans, Grafted, 4 to 5 tit., whips

45.00

500 Pecans, Grafted, 3 to $4 \mathrm{ft}$., whips

35.00

1600 Pecans, Grafted, 2 to 3 ft., whips

27.50

500 Pecans, Grafted, 1 to $2 \mathrm{ft}$. , whips

Varieties: Delmas, Frotscher, Stuart, Schley, Success, Van Deman.

120 Pecans, Seedlings, 6 to $8 \mathrm{ft}$, , few branches.

35.00

800 Pecans, Seedlings, 2 to $3 \mathrm{ft}$., whips............................................... 15.00

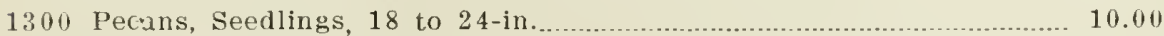

2500 Pecans, Seedlings, 18 -in.

6.00

300 Walnut, English, 18 to 24 -in., whips

17.50

6000 Walnut, English, 12 to 18-in., whips

10.00

350 Walnut, Japan, 8 to $10 \mathrm{ft}$, branched

50.00

300 Walnut, Japan, 6 to $8 \mathrm{ft}$, branched

40.00

200 Walnut, Japan, 5 to $6 \mathrm{ft}$., mostly whips.

35.00

150 Walnut, Japan, 4 to $5 \mathrm{ft}$, mostly whips.

25.00

200 Walnut, Japan, 3 to $4 \mathrm{ft}$., whips

20.00

800 Walnut, Japan, 2 to $3 \mathrm{ft}$., whips

15.00

600 Walnut, Japan, 18 to 24 -in.

10.00

500 Walnut, Japan, 12 to 18 -in

5.00

Tarieties: cordiformis, Sieboldiana.

\section{GRAPES.}

New York grown, except Scuppernong.

Per 1,000

$\$ 35.00$

2200 Concord, 2 year No. 1

20.011

1600 Concord, 1 year No. 1

50.00

200 Diamond, 2 year No. 1

40.00

400 Diamond, 1 year No. 1

45.00

400 Ives, 2 year No. 1

35.00

450 Ives, 1 year No. 1

75.00

800 Lutie, 2 year No. 1

50.00

250 Moores Early, 2 year No. 1

40.00

100 Noores Early, 1 year No. 1 


\section{GRAPES-Continued}

300 Niagara, 2 year No. 1 50.00

1000 Niagara, 1 year No. 1 40.00

550 Worden, 1 year No. 1

280 Scuppernong, White, 2 year No. 1.

230 James, Black, 2 year No. 1

100 Flowers, 2 year No. 1

80 Thomas, 2 year No. 1

\section{SMALI, FRUYTS}

Per 1,000 $\$ 12.50$

2300 Early Harvest Blackberry

12.50

650 McDonald Blackberry

300 Austin Dewberry

500 Lucretia Dewberry

800 King Raspberry

1200 St. Regis Raspberry.

400 Columbian, Tips

500 Cumberland, Tips.

300 Assorted Currents, 2 year No. 1

700 Houghton Gooseberry, 2 year No. 1.

3000 Conover's Asparagus, 2 year No. 1.

\section{RASPBEIRRIES IN MICHIGAN}

We offer the following for shipment from Bridgman, Michigan, after March 15 th; prices boxed and F. O. B. there:

16,000 Cuthbert

Per 1000

$10,000 \mathrm{King}$ $\$ 6.50$

4,500 Kansas, Tips 6.50

4,500 Columbian, Tips 7.00

3,000 St. Regis

\section{STRAIIERRY PIANTS}

For direct shipment from our grower in the Chattanooga district, prices F. O. B. shipping point:

Excelsior Prr 1000

Lady Thompson

Missionary

St. Louis

Klondyke

Aroma

Gandy

Progressive, Everbearing

Superb, Everbearing

Texas, Everbearing 
Anerican Apple, No. 1, 3/16 and up, straight roots

American Apple, No. 2, $2 \frac{1}{2}: 16$ to $3 \frac{1 / 2}{2} / 16$, straight roots........................... 3.50

Anerican Mahaleb, No. 1, 4 to $6 \mathrm{~mm}$................................................... 10.00

Pear, Japan, No. 1, 3,16 and up, straight roots ........................................ 15.00

Pear, Japan, No. 2, $2 / 16$ to $3 / 16$, straight roots........................................... 12.50

Prices include boxing.

\section{APIIST SCIONA}

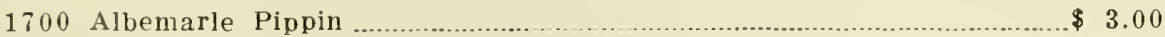

800 Ben Davis ........................................................................................ 3.00

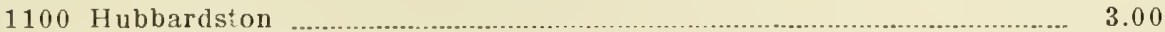

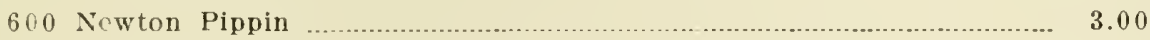

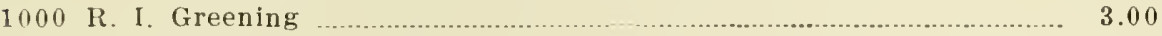

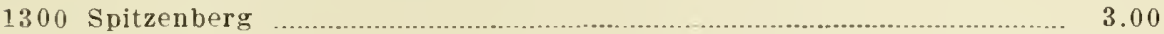

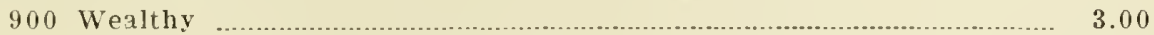

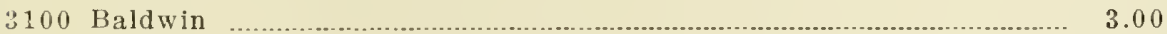

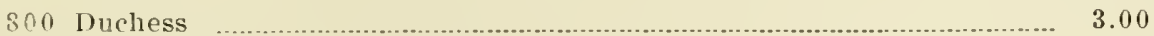

$1 \therefore 00$ Gravenstein …..................................................................................... 3.00

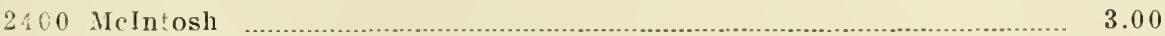

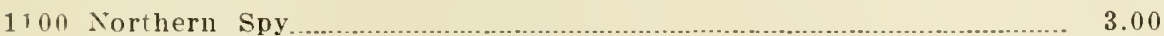

3000 Red Astrachan …........................................................................ 3.00

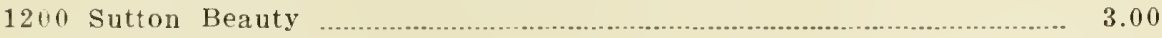

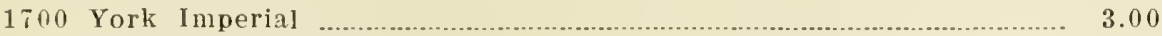

Price includes boxing.

\section{ORNAMENTAL DEPARTMENT}

\section{VINES}

Per 100

200 Ampelopsis Engelmanii No. 1

$\$ 12.00$

200 Ampelopsis Engelmanii, Medium

8.00

600 Ampelopsis Quinquefolia, 2 year No. 1

10.00

600 Ampelopsis Quinquefolia, 2 year Medium.

7.50

300 Ampelopsis Veitchii, 2 year Medium

12.50

sin Ampelopsis Veitchii, 2 year No. 2

9.00

51) Cle in at is Jackmanii, 2 year No. 1

18.00

150 Clematis Henryii, 2 year No. 1

20.00

125 Clematis Mad. Andre, 2 year No. 1

18.00

500 Clematis Paniculata, 2 year No. 1

12.50

700 Clematis Paniculata, 2 year Medium

200 Euonymus Vegetus, 2 year.

1600 Kudzu, 2 year

foo Halls Japan Honeysuckle, 2 year No. 1

1400 Halls Japan Honeysuckle, 1 year No. 1

600 Scarlet Trumpet Honeysuckle, 2 year No. 1

3500 Scarlet Trumpet Honeysuckle, 1 year No. 1

250 Japan Golden Honeysuckle, 2 year No. 1 
ABELAN GRINDIFLORA

1803 to 4 feet

Per 100

900 2 to 3 feet

120018 to 24 inches.

110015 to 18 inches

HUXUS SUFFRETICOSA (Dwarf BOox) :

3006 to 8 inches

12003 to 5 inches

HONYMUS JAPONICA:

35012 to 15 inches

4008 to 12 inches

GMRINAIA (Cape Jasmine):

1001 year in 4 inch pots.

1501 year in 3 inch pots

IAUROCERASTS (English Laurel) :

4030 to 36 inches

6024 to 30 inches

14018 to 24 inches

24015 to 18 inches

MAGNOLA GRANIIFLORA:

305 to 6 feet

$\$ 125.00$

454 to 5 feet

100.00

553 to 4 feet

60.00

1202 to 3 feet

9018 to 24 inches

MAHONIA AQUHOLIA (Holly Leaved MaLonia):

50 18-inch

\section{BIROAD-LEAVED EVERGREENS}

Prices quoted on Broad-Leaved Evergreens are for plants dug with naked roots and puddled in thick mud. If wanted baled and burlapped add 5 cents each for sizes under 2 feet, 10 cents each for 2 to 3 feet, 15 cents for 3 to 4 feet, and 25 cents for 3 feet and larger. We defoliate Magnolia Grandiflor: before digging.

\section{CONHERS}

Varieties marked with a * are priced baled and burlapped; where star is not shown prices are for plants dug with puddled roots. If wanted baled and burlapped there will be an additional charge as follows:

Plants under 2 feet

Plants 2 to 3 feet.

Plants 3 to 4 feet

5 cents

Plants 4 to 5 feet.

8 cents

10 cents

15 cents

\section{AbIES, GXCEISA (Nomay spruce):}

$150 \quad 30$ to 36 inches

Per 100

15024 to 30 inches

10018 to 24 inches

But A, ORIINTALAs (Chinese Arborvitae):

405 to 6 feet

$\$ 100.00$

1204 to 5 feet

75.00

1103 to 4 feet

50.00

$50 \quad 30$ to 36 -in.

40.00

miotA, OHIENTAIS ACRIA (Chinese Golden Arborvitae):

5024 to 30 inches

18018 to 24 inches

15015 to 18 inches

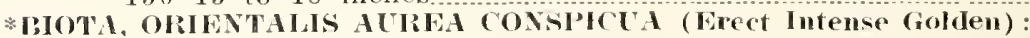

4030 to 36 inches.

3024 to 30 inches

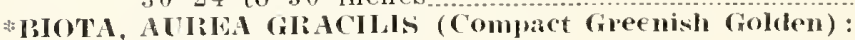




\section{CONIFERS-Continued}

*IBOTA, MCREA NANA (Berckman's Dwarf Golden):

5018 to 24 inches

*IBIOTA, ALIRA PYRAMIDALIS (PYramidal Golden):

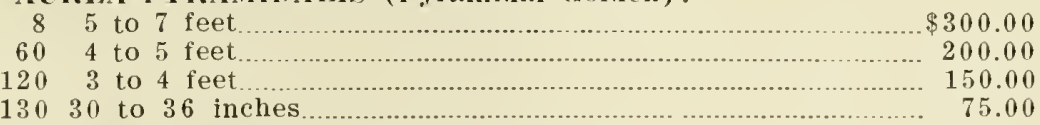

*IBOTA, ELEGANTISSIMA (Rollinson's Golden):

304 to 5 feet

"IBIOTA, SEMIREAURESCENS (Fvergolden) :

5024 to 30 inches.

*IBOT I, IROSEDALE:

1530 to 36 inches

$\$ 100.00$

2524 to 30 inches.

80.00

2518 to 24 inches

50.00

\#RTDI'S NTLANTICA GLALCA:

205 to 6 feet

304 to 5 feet

103 to 4 feet

150.00

\section{* ('EDIRLS IDEOARA:}

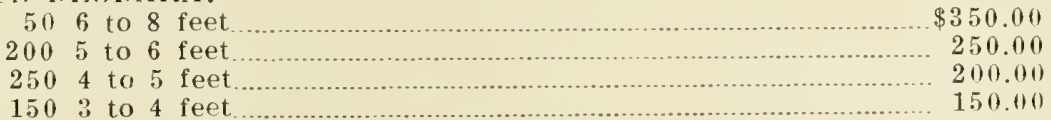

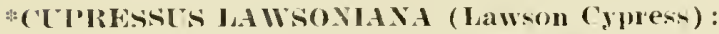

10 Specimens 8 to 10 feet, each.

COPIRESTS TRITUPH DE BOSKOOP:

2 Specimens 8 to 10 feet, each.

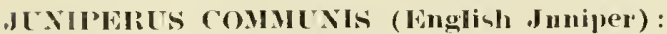

1503 to 4 feet.

10024 to 30 inches.

JUNIPIRL' HIBERNI(A (Irish Juniper):

1003 to 4 feet

40030 to 36 inches.

80024 to 30 inches.

2.0 .00

120018 to 24 inches.

15.00

JINIIJIL's VIRGINIANA (Virginia Red Cedar):

105 to 6 feet

$\$ 175.00$

154 to 5 feet

150.00

100.00

253 to 4 feet

2530 to 36 inches.

75.011

ATIPLILS VIRGINIANA GLAUCA:

105 to 6 feet

104 to 5 feet

ARTIMONIOLA PLEMOSA:

303 to 4 feet

\#RYTIOSPORA PICMOSA ALREA:

503 to 4 feet 
THEVA OCCIDENTtLS (American Arborvitae):

204 to 5 feet

10030 to 36 inches

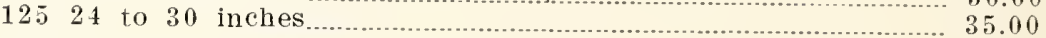

FTSLGA CANADENSIS (Hemlock spruce):

3024 to 30 inches.

10018 to 24 inches

12515 to 18 inches

\section{SHAIE THEFS}

\section{A(wli, DAsYCARPLI (Silver Maple):}

15012 to 15 feet, 2 to $2 \frac{1}{2}$ inch caliper.

Per 100

$\$ 100.00$

30012 to 14 feet, $13 / 4$ to 2 inch caliper.

35010 to 12 feet, $1 \frac{1 / 2}{2}$ to $1 \frac{3 / 4}{4}$ inch caliper

2009 to 11 feet, $1 \frac{1}{4}$ to $1 \frac{1}{2}$ inch caliper.

40.60

3008 to 10 feet, 1 to $1 \frac{1 / 4}{4}$ inch caliper.

25.00

6006 to 8 feet

15.00

2505 to 6 feet

10.01

ACER, DASYCARPUM WEIRI (Weir's Cut Leaf Maple):

5012 to 15 feet, 2 to $2 \frac{1}{2}$ inch caliper

7510 to 12 feet, $13 / 4$ to 2 inch caliper

5010 to 12 feet, $1 \frac{1 / 2}{2}$ to 2 inch caliper.

ACLR PLATANOHES (Norway Maple):

1258 to 10 feet

3006 to 8 feet

ACER SACCHARUM (Sugar Maple):

3010 to 12 feet, $1 \frac{1 / 4}{4}$ to $1 \frac{1 / 2}{2}$ inch caliper

$\$ 75.00$ 50.60

1508 to 10 feet

2806 to 8 feet

2505 to 6 feet

CATALPA IBUNGEII:

1502 year heads, 5 to 7 feet stems.

1002 year heads, 4 to 5 feet stems.

CHRCIS CANADENSIS (Red liud):

806 to 8 feet

1205 to 6 feet

1504 to 5 feet

2003 to 4 feet

2502 to 3 feet.

CORNUS FLORIDA (BogwOOd):

758 to 10 feet

1506 to 8 feet

1005 to 6 feet

3002 to 3 feet

50018 to 24 inches

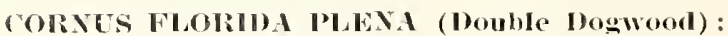

506 to 8 feet

CORNUS HLORIDA RUBRA (Red Pogwood): 
Koglifuteria PANiculata (Vamish Tree):

1508 to 10 feet

LIRIODENDRON TLLIPIFERA (Tulip Poplar) :

505 to 6 feet

MAGNOLIA TIIPETALA:

1008 to 10 feet

1006 to 8 feet.

MHLA AZEDERACH UMBRACLLIFORMIS ('Texas Umbrella):

2505 to 6 feet, 1 year whips

3004 to 5 feet, 1 year whips

4003 to 4 feet, 1 year whips

6002 to 3 feet, 1 year whips

MOREA ALIBA PLNIULA ('Teas Weeping Mubery):

3002 year heads, 5 to 6 feet stems

752 year heads, 3 to 4 feet stems.

601 year heads, 5 to 6 feet stems.

I'RRSICA ALIBA PLENA (Double White Peach):

505 to 6 feet, well branched

1204 to 5 feet, well branched.

3503 to 4 feet, branched

982 to 3 feet, lightly branched.

10.00

701 to 2 feet, mostly whips

7.50

PERSICA RUIBIA PLENA (Double Red Peach):

1005 to 6 feet, well branched.

1954 to 5 feet, well branched

4453 to 4 feet, well branched.

12.50

1502 to 3 feet, lightly branched.

1071 to 2 feet, mostly whips

7.50

PIATANLS OCCIDENTALIS (American Sycanore):

15012 to 15 feet, 2 to $2 \frac{1}{2}$ inch caliper.

25010 to 12 feet, $13 / 4$ to 2 inch caliper

30010 to 12 feet, $1 \frac{1 / 2}{2}$ to $1 \frac{3 / 4}{4}$ inch caliper.

3509 to 11 feet, $1 \frac{1 / 4}{4}$ to $1 \frac{1}{2}$ caliper.

4008 to 10 feet

4006 to 8 feet

25.00

4005 to 6 feet

PLATANCS ORIENTALIS (European sycamore):

25010 to 12 feet, $1 \frac{1 / 4}{4}$ to $1 \frac{1}{2}$ inch caliper.

3508 to 10 feet.

2506 to 8 feet.

POIPULCS, CAROLINIENSIS (Carolina Poplar) :

20010 to 12 feet, $1 \frac{1 / 4}{4}$ to $1 \frac{1 / 2}{2}$ inch caliper

4008 to 10 feet

4006 to 8 feet

IPOIPLCS NIGRA ITALICA (Lombardy Poplar):

3008 to 10 feet

2006 to 8 feet

5005 to 6 feet, 1 year.

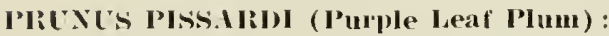

354 to $5 \mathrm{ft}$.

373 to $4 \mathrm{ft}$

202 to $3 \mathrm{ft}$. 
PYRCS FIORIBUNDA:

984 to $6 \mathrm{ft}$.

1503 to $4 \mathrm{ft}$.

682 to $3 \mathrm{ft}$.

161 to $2 \mathrm{ft}$.

PYRUS FLORIBLNDA ATROSANGUINEA:

504 to $6 \mathrm{ft}$.

2183 to $4 \mathrm{ft}$.

1702 to $3 \mathrm{ft}$

401 to $2 \mathrm{ft}$.

PYRUS NIFDZWETZKYaNa (Puple Leaf):

1004 to $6 \mathrm{ft}$.

1503 to $4 \mathrm{ft}$.

402 to $3 \mathrm{ft}$

PYRES PARKMANII:

123 te 4 ft

$\$ 35.00$

332 to $3 \mathrm{ft}$

91 to $2 \mathrm{ft}$.

PYRTS SCHEIDECIKERI :

103 to $4 \mathrm{ft}$.

222 to $3 \mathrm{ft}$

151 to $2 \mathrm{ft}$.

PYRUS SPECTABILIS:

93 to $4 \mathrm{ft}$.

402 to $3 \mathrm{ft}$.

201 to $2 \mathrm{ft}$.

QUERCUS PALUSTRIS (Pin Oak) :

208 to $10 \mathrm{ft}$.

$\$ 125.00$

206 to $8 \mathrm{ft}$.

100.00

405 to $6 \mathrm{ft}$.

75.00

TILIA AMERICANA (American Linden):

1010 to $12 \mathrm{ft}$.

208 to $10 \mathrm{ft}$.

206 to $8 \mathrm{ft}$.

155 to $6 \mathrm{ft}$.

50.00

ULMLS AMERICANA (American Elm):

15010 to $12 \mathrm{ft} ., 1 \frac{1 / 4}{4}$ to $1 \frac{1 / 2}{\text { inch }}$

$\$ 50.00$

2008 to $10 \mathrm{ft}$

35.00

1506 to $8 \mathrm{ft}$.

25.00

1505 to $6 \mathrm{ft}$.

20.00

4004 to $5 \mathrm{ft}$.

10.00

\section{DECIOUOUS SHREBS}

ILTHEA, BUSH FORM :

4 to $5 \mathrm{ft}$., well branched.

AIL

3 to $4 \mathrm{ft}$., well branched

AINI

2 to $3 \mathrm{ft}$., well branched.

10.00

Amplissima, double red.

Anemonaeflorus, double rose

Boule de Feu, double red 
ALTHEA, TREF FORM:

\begin{tabular}{|c|c|c|c|c|}
\hline \multirow{2}{*}{\multicolumn{5}{|c|}{ 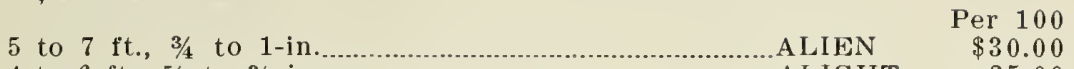 }} \\
\hline & & & & \\
\hline 4 to $6 \mathrm{ft} ., 5 / 8$ to $3 / 4-i n . \ldots \ldots \ldots \ldots \ldots \ldots \ldots \ldots \ldots \ldots \ldots \ldots \ldots \ldots \ldots$ & & ALIG & HT & 25.00 \\
\hline 4 to $5 \mathrm{ft} ., 9 / 16$ to $5 / 8$-in......... & & ALIV & & 20.00 \\
\hline $31 / 2$ to $5 \mathrm{ft} ., 1 / 2$ to $9 / 16$-in.... & & ALAS & & 15.0 \\
\hline & $3 / 4-1^{\prime \prime}$ & $\begin{array}{c}5 / 8-3 / 4 " \\
45\end{array}$ & $\begin{array}{c}9-16-5 / 8 \\
132\end{array}$ & $1 / 2-9-1$ \\
\hline & & & 25 & \\
\hline & 67 & 30 & 30 & \\
\hline & 52 & 47 & 5 & \\
\hline & 10 & 6 & & \\
\hline & .... & ….... & 17 & \\
\hline
\end{tabular}

Anemonaeflorus

Boule de Feu

Jeanne d'Arc

Monstrosus

Snow drift

Souvenir Chas. Breton

Per 100

$\$ 15.00$

12.50

17730 to $36-\mathrm{in}$.

10.00

180018 to $24-$ in.

8.00

IBERIBERIS PULPITEA (P'Mple Barbery):

30018 to 24 inches.

BERIBERIS THUNBLRGII (Thunbera's Barbery):

50030 to 36 inches

$\$ 15.00$

120024 to 30 inches

12.00

250018 to 24 inches

8.00

400015 to 18 inches.

300012 to 15 inches.

6.00

5.00

ICDDLEIA LINDLEYANA (Chinese Buddleia) :

4001 year.

$\$ 10.00$

IBCDDEIA DAVIDI MAGNIFICA (Butterfy bush):

13002 year, field grown.

2001 year in 3 -inch pots

$\$ 12.50$

10.00

(AIranthos hoolines (sweet shrub):

3503 to 4 feet

7502 to 3 feet

$\$ 17.50$

15.00

67018 to 24 inches

12.50

125012 to 18 inches

7.50

(YDONIA, JAPONICA (Japan Quince):

2003 to 4 feet

$\$ 15.00$

6002 to 3 feet

12.50

50018 to 24 inches

10.00

('ORNUS STOLONIFERA (Native Red Osier):

2003 to 4 feet

$\$ 15.00$

3002 to 3 feet

10.00

('RATAEGLS CRLS GALIL (Cockspur Thom) :

643 to 4 feet

Per 100

562 to 3 feet

$\$ 35.00$

301 to 2 feet

25.00

15.0

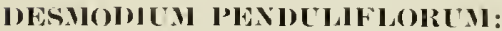

100 in 4 -inch pots

DESMOIIUM, WHITE:

$\$ 20.00$

100 in 3 -inch pots

$\$ 25.00$

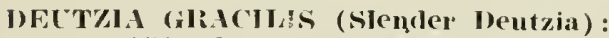

15012 to 15 inches

$\$ 10.00$

DECTYIA PIRIDE OF ROCHESTHR:

3004 to 5 feet

2503 to 4 feet

$\$ 12.50$

10.00

DELTZIA (TRENATA ROSEO FL IPL:

294 to 5 feet

HOISTTHIA INTEIRIEDIA:

2002 to 3 feet

25018 to 24 inches 
FORSYTHIA SUSPENSA :

674 to 5 feet

1302 to 3 feet

HYPERICUM MOSERIANUM (Gold Flower) :

450.2 year

HYDRANGEA P. G., Tree Form:

3004 to 5 feet

$\$ 30.00$

HYDRANGEA P. G. Bush Form:

7002 to 3 feet

$\$ 12.50$

120018 to 24 inches

HYDRANGEA A. G. (Hills of Snow):

50030 to 36 inches.

140024 to 30 inches

125018 to 24 inches.

IAAERSTRObila INDICA (Pink Crepe Myrtle):

2004 to 5 feet.

3203 to 4 feet

4502 to 3 feet

66018 to 24 inches

48512 to 18 inches

LONICERA FRAGRANTISSIMA (Fragrant Honeysuckle) :

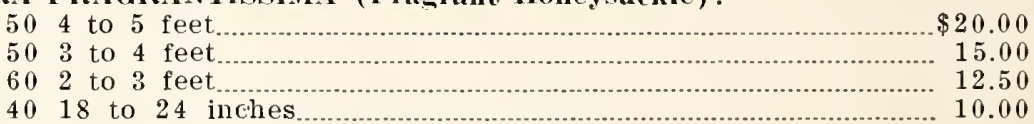

LONICERA MORROWII (Japan Bush Honeysuckle) :

1503 to 4 feet

2602 to 3 feet

18018 to 24 inches

LONICERA TARTARICA ALBA (White Tartarian Honeysuckle):

853 to 4 feet

1502 to 3 feet

12.50

28018 to 24 inches

8.00

15012 to 18 inches

IONICERA TARTARICA ROSEA (Pink Tartarian Honeysuckle):

1252 to 3 feet.

$\$ 12.50$

8.00

26018 to 24 inches.

5.00

IONICERA TARTARICA RLPRA (Red Tartarian Honeysuckle):

853 to 4 feet

2402 to 3 feet

$\$ 15.00$

23018 to 24 inches

12.50

8.00

48012 to 18 inches

5.00

PHILADELPHUS GRAXIFLORUS (Large Flowering Syringa):

1874 to 5 feet

$\$ 15.00$

1403 to 4 feet

12.50

3702 to 3 feet

8.00

42518 to 24 inches

35012 to 18 inches.

PHILADELPHES MONT BLANC (Hybrid Syringa):

203 to 4 feet

702 to 3 feet

3518 to 24 inches

12.50

I'IRUNUS TRILOBA (Double Flower Plum):

6018 to 24 inches

7512 to 18 inches

RHUS COTINUs (Purple Fringe):

504 to 5 feet 
SPIREA ANTHONY WATERER:

17015 to 18 inches.

4008 to 12 inches.

SPIREA ARGUTA :

1003 to 4 feet

SPIREA PRUNIFOLIA HL PL:

1004 to 5 feet

1503 to 4 feet

1002 to 3 feet

10018 to 24 inches

SPIREA REEVESIANA:

3154 to 5 feet

5903 to 4 feet

5018 to 24 inches

SPIREA THUNIBERGII:

80015 to 18 inches $\$ 10.00$

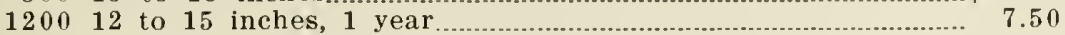

SPIREA VAN HOUTTE:

6004 to 5 feet

$\$ 15.00$

8003 to 4 feet

12.50

35002 to 3 feet

10.00

400018 to 24 inches

6.00

500018 to 24 inches, 1 year

4.00

SYMPHORICARPOS RACEMOSL' (Snowberry):

203 to 4 feet

1102 to 3 feet

12.50

50018 to 24 inches

10.00

50012 to 18 inches

SYMPHORICARPOS VULGARIS (COMal Berry) :

6002 to 3 feet

$\$ 10.00$

80018 to 24 inches.

SYRINGA VULGARIS (Purple Lilac):

15018 to 24 inches.

SYRINGA VULGARIS (Named solts)

1802 to 3 feet.

50 Chas. X.

50 Mad Lemoine

30 Marie LeGraye

50 Souv de Ludwig Spaeth

SYRINGA VILLOSA (Himalayan Lilac):

802 to 3 feet

15018 to 24 inches

TAMARIX ODESSANA:

503 to 4 feet

752 to 3 feet

VIBURXU OPLIUS (Highbusin Cranberry) :

$30 \quad 2$ to 3 feet

6818 to 24 inches

VIBLRNEY OPULCS STERILIS (Common snowball) :

402 to 3 feet

14018 to 24 inches

51012 to 18 inches

VIILRNCM LANTANA (Wayfaring Tree):

303 to 4 feet 
VITEX AGNUS CAsTus (Chaste Tree):

2003 to 4 feet

WIEIGLIA CANDIDA:

2504 to 5 feet

1502 to 3 feet

WHIGELIA ROSEA:

584 to 5 feet

$\$ 20.00$

WE:(AELIA VARIEGATED:

$70 \quad 3$ to 4 feet

$\begin{array}{llll}60 & 2 & \text { to } & 3 \\ \text { feet }\end{array}$

$\$ 20.00$

15.00

Shrubs are all 2 years old and bushy, except as noted. Graded RIGHT, will suit. 4 to 5 feet tied in bundles of 5 ; all others in 10 's, except 12 to 18 inches, which are tied in 25's. Please make your orders accordingly.

\section{PRIVIT}

P'RIVIT, AMOOI RIVER NORTH:

20003 to $4 \mathrm{ft}$., heavy.

Per 1,000

8003 to $4 \mathrm{ft} .$, light

$\$ 100.00$

60.00

35002 to $3 \mathrm{ft}$, heavy

60.00

16002 to $3 \mathrm{ft}$,, light.

40.00

350018 to 24 -in., heavy.

40.00

200018 to 24 -in., light.

400012 to 18 -in., heavy

25.00

300012 to 18 -in., light

25.00

20.00

10000 Transplanting

12.50

PIRIVHT, AMOOR LIVIER SOETH:

25002 to $3 \mathrm{ft}$., well branched

$\$ 30.00$

350018 to 24 -in., well branched

25.00

300012 to 18 -in., well branched

17.50

PRIVET, CALIIORNIA:

35004 to $5 \mathrm{ft}$., heavy.

$\$ 40.00$

60003 to $4 \mathrm{ft}$., heavy.

35.00

25003 to $4 \mathrm{ft}$., light.

20.00

80002 to $3 \mathrm{ft}$., heavy.

20.00

40002 to $3 \mathrm{ft}$, light

17.50

12.50

600018 to 24 -in., light

10.00

1500012 to 18 -in., light

7.50

150006 to 12 -in., heavy.

5.00

PIRIVET, IBOT A :

3603 to $4 \mathrm{ft}$., well branched

$\$ 100.00$

7402 to $3 \mathrm{ft}$., well branched

31018 to 24 -in., well branched

40.00

7512 to 18 -in., well branched

5000 Transplanting

IPRIVIET, POIASH:

50018 to 24 -in., well branched

150012 to 18 -in., well branched

20006 to 12 -in., well branched

2000 Transplanting

Roses-Own Roots, Two Year

Grades: $\mathrm{XX}, 30$ to 36 -inch, according to habit of growth; No. 1,18 to 30 -inch; No. 2, 12 to 18 -inch. XX's tied in bundles of 5 , others in bundles of 10. Please make your orders accordingly.

150 American Pillar, No. 1

50 Blumenschmidt, No. 1

250 Blumenschmidt, No. 2

300 Catherine Zeimet (White Baby), No. 1 


\section{ROSES-Continued}

500 Catherine Zeimet, No. 2

120 Climbing American Beauty, No. 1.

75 Climbing American Beauty, No. 2

110 Climbing Gruss an Teplitz, XX

10.00

180 Climbing Gruss an Teplitz, No. 1

20.00

120 Climbing Gruss an Teplitz, No. 2

15.00

10.00

33 Climbing Helen Gould, No. 1

250 Crimson Rambler, XX

800 Crimson Ramblel, No. 1

400 Dorothy Perkins, XX.

15.00

700 Dorothy Perkins, No. 1

12.00

90 Flower of Fairfield, No. 1

15.00

425 Flower of Fairfield, No. 2.

10.00

100 Farquhar, No. 1.

12.00

65 Gruss an Teplitz, No. 1

18.00

170 Gruss an Teplitz, No. 2

12.00

2 Glorie Margottin, No. 1

28 Glorie Margottin, No. 2

18.00

12.00

120 Francesca Kruger, No. 1

20.00

15.00

15.00

70 Mad. Caroline Testout, No.

20.00

15.00

15.00

400 Marie Van Houtte, No. 2

20.00

Maman Cochet,

15.00

15.00

160 Mrs. B. R. Cant, No. 2

12.00

2300 Madam Plantier, No. 1

200 Philadelphia, XX.

15.00

12.00

600 Philadelphia, No. 1.

100 Rugosa Alba, No. 1.

100 Rugosa Alba, No. 2.

15.00

10.00

10.00

7.50

200 Rugosa Rubra, No. 2

12.00

375 Tausendschon, No. 2

12.00

20.00

200 William R. Smith, No. 1

15.00

15.00

200 White Cochet, No. 2 .

12.00

210 White Rambler, No. 1

ROSES-No. 3

Per thousand

Recommended only for lining out. Own lorots.

550 Catherine Zeimet.

2100 Dorothy Perkins.

200 Lady Gay.

3900 Queen of Prairie.

3500 Crimson Rambler.

550 Flower of Fairfield.

2400 Madam Plantier.

2300 White Perkins.

ROSES-NO, :3

Per thousand

80 Mad. Caroline Testout.

350 Wm. R. Smith

280 Maman Cochet.

$\$ 60.00$

These Hybrid Teas carry only about 8 inches of wood; not much goorl.

ROSHS-Budded, Home Grown

260 American Beauty, No. 1

Per 100 $\$ 25.00$

360 American Beauty, No. 2

25 Arne Diesbach, No. 1.

18.00

18.00

20.00

310 Frau Kärl Druschki, No. 1

20 Frau Karl Druschki, No. 2

17.50

18.00

100 Crested Moss, No. 1

85 Gruss an Teplitz, No. 1

15.00

18.00

30 Henri Martin (Red Moss), No. 1

20.00 


\section{ROSES-Continued}

16 J. B. Clark, No. 2

110 Laurent Carle, No. 1

23 Laurent Carle, No. 2

50 Magna Charta, No. 1

$100 \mathrm{Mad}$. Gabriel Luizet, No. 1.

150 Marechal Neil, No. 1

200 Paul Neyron, No. 1

75 Paul Neyron, No. 2

125 M. P. Wilder, No. 1

40 Salet Moss, No. 1

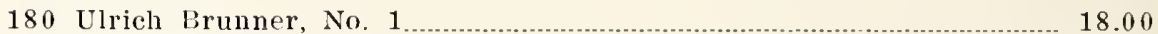

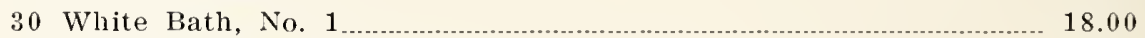

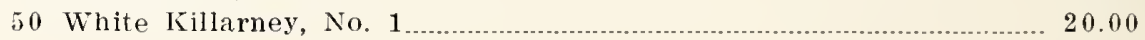

\section{TRANSPLANTING STOCK}

Home grown; prices include boxing. If you expect to get these items at quoted prices make your orders in multiples of 100 .

Boule de Feu.

Double Red.

Jeanne d'Arc.

\section{Carnea Plena.}

Touble Purple.

Lady Stanley.

AMPELOPSIS VEITCHII, 1 year Seedlings. 


\section{NURSERYMEN'S SUPPLIES}

\section{I'ROMIJT SHILMENT}

All supply orders (except printed matter) are usually shipped next train after receipt. We try to carry a complete stock at all times. Our location at Chase gives us unsurpassed facilities for quick action on rush orders - two lines of railway at our doors.

\section{ADVANCED PRICES}

Notice.-Prices on almost all Supplies change every few minutes and we cannot guarantee these prices longer than our present stock lasts. Will always make best price we can.

\section{K NIVIS}

Made especially for us by a manufacturer who is "fussy" about the quality of his output. Have used and handled these knives for twenty years.

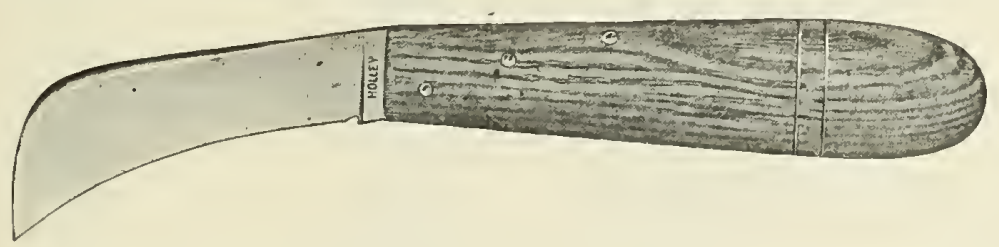

C. A. (x. PRUNAR-Stationary hardle; full length 8 inches; length of blade $3 \frac{1}{4}$ inches; well balanced "hook" and easy on the operatol. Handle of hardwood fastened with three rivets set diagonally. After testing out this knife in our own work we have decided to offer it to the trade as the best Pruning Knife of reasonable cost that we can find. Price, $50 c$ each, postpaicl; $\$ 5.00$ per dozelı, postage extra.

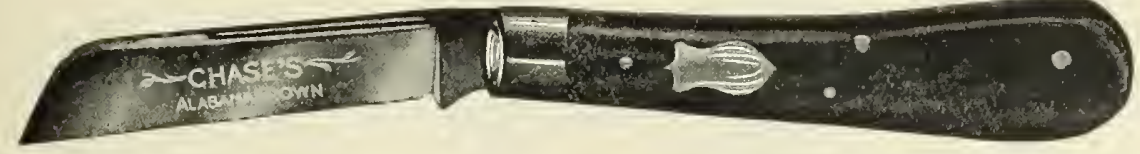

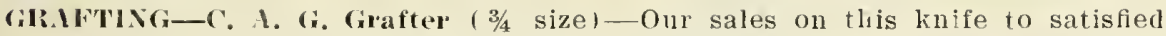
nurserymen and florists are more than five hundred dozen. It is more knife for grafting and general use for the money than any on the market. Makes a good serviceable pocket knife. Cocoa handle; 40 s each, postpair; $\$ 4.25$ per dozen, postage extra.

\section{PRUNING SHEARS-GPECIAL HEIVI AMEITCAN}

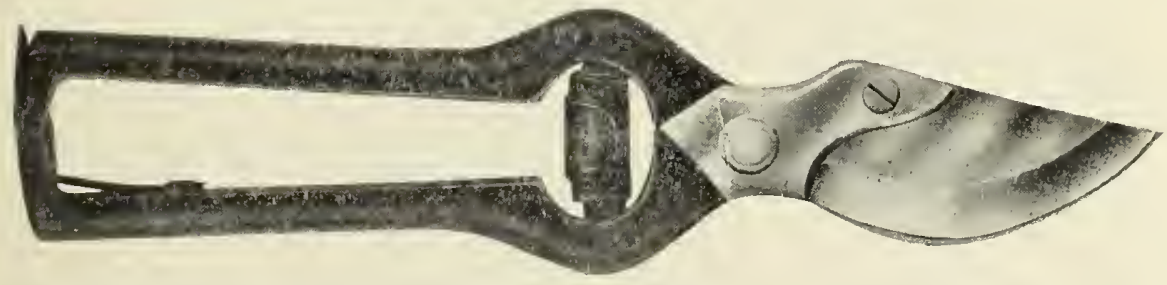

HXTRI HEIVI, weight 16 ounces; volute steel spring. Not highly finished, but as ready as they are rough, and big value at the low price of $75 \mathrm{c}$ per pair, postpaid; per dozen, $\$ 7.50$, postage extra. Half dozen at dozen rates. 


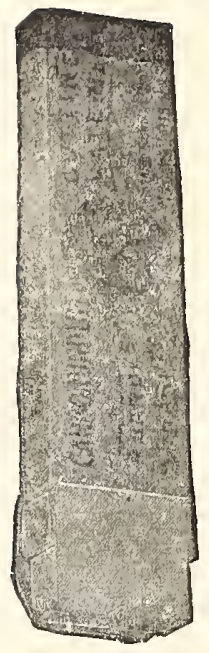

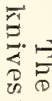

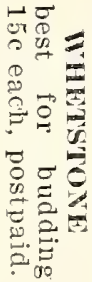

芑

or

Е

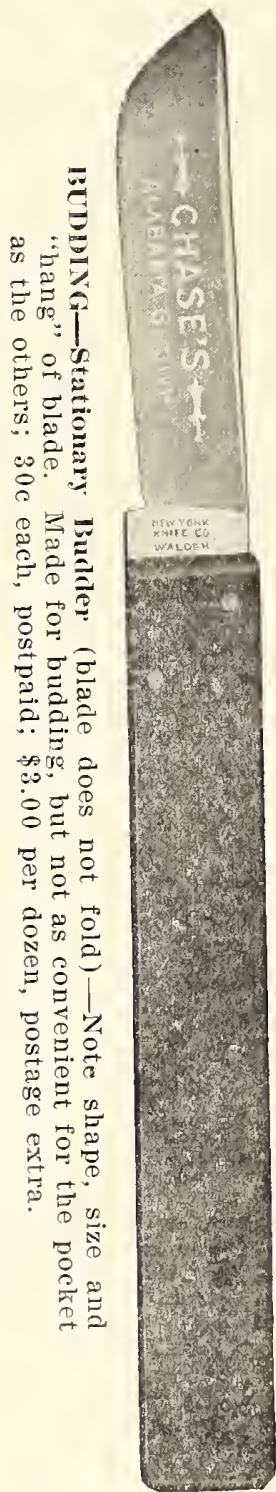

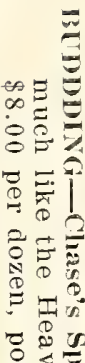

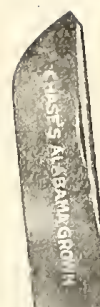

幽

O०

(1) (8)

(D)

क्ष

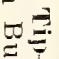

है।

ت 8

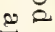

污

:

పี

쿠

D.

-

80

롤

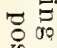

总

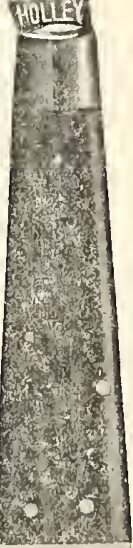

(2)

范苛

늘

․ㅜㄹ

을

웅

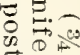

है.

2.

○े

卢志.

(2) थ

름

유요.

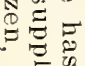

क्ष

er 8

$0 \%$

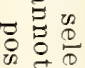

कै

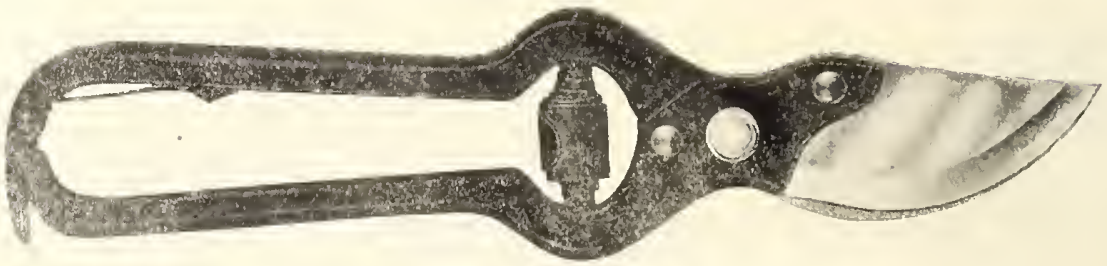

MVRICAN, () inches-This is a low-priced, good, well built, all around prunin shear. Have handled these for years and they give full value in service. Weight, 14 ounces; volute steel spring. Per pair, postpaid, 65 c; per dozen, freight 6 express, $\$ 6.50$. Half dozen at dozen rate. 


\section{PIITING SHWARS-Continned}

THI WATCH SPIING FRENCH SHEARS stand at the head of the list for making cuttings of all kinds. For cutting back seedlings to the bud or any heavy work the 9-inch is recommended.

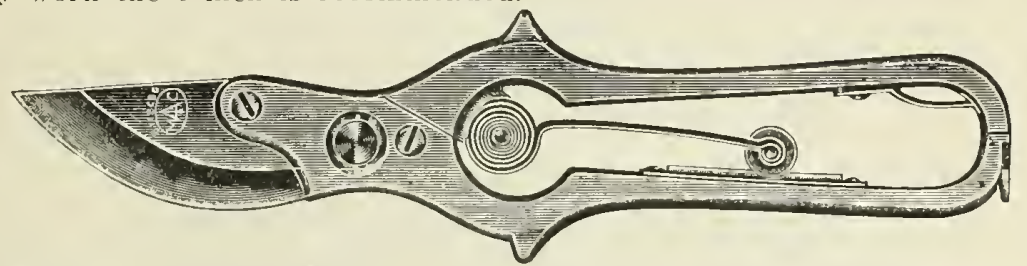

WATCH SHING, FRFNCH, 9-inch-Per pair, postpaid, $\$ 2.50$; per dozen pairs, freight or express (weight per dozen pairs, 11 lbs.), $\$ 24.00$.

WATCII SIRING, HIRNCH, 8 inches-Per pair, postpaid, $\$ 2.10$; per dozen pairs, freight or express (weight per dozen pairs, 7 lbs.), $\$ 21.00$.

WATCH SIRING, FIRENH, ( inches--Per pair, postpaid, $\$ 1.50$; per dozen pairs, freight or express (weight per dozen pairs, $5 \frac{1}{2} \mathrm{lbs}$ ) , $\$ 16.00$.

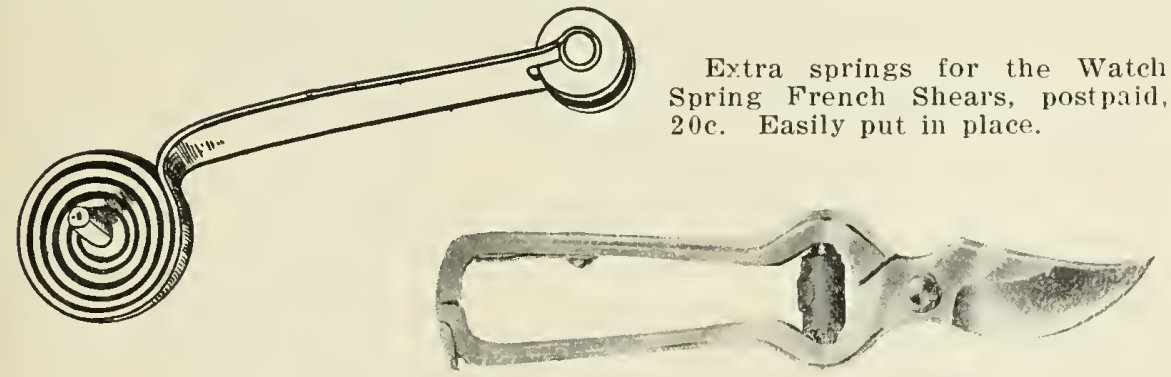

Ladlies' l'rnning Shear's, G-inch, Heavily Nickeled

LADIFS" proNING SHEARs, 6 inches- "Made in America" and, in our judgment, the best Ladies' Pruning Shears. Beautifully finished, shaped just right, ligh quality throughout. For all light work, for use around the roses, shrubs, etc., it just fills the bill. Per pair, postpaid, $\$ 1.00$; per dozen, postage extra, $\$ 10.75$.

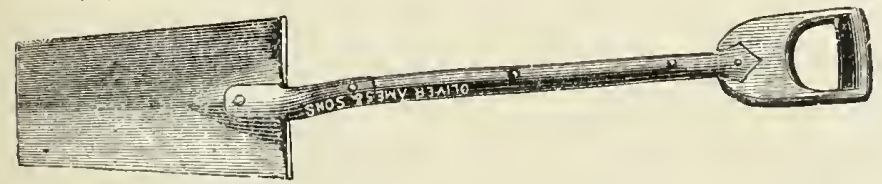

Alfs NTRSBRY SPADE-D handle, double strapped full length of handle, tapered nursery spade; size of blade, $12 \frac{3}{4} \times 7 \frac{1}{2} \times 5 \frac{1}{2}$; weight, 9 pounds; $\$ 2.00$ each, $\$ 24.00$ per dozen.

HXThA SRADE HANDLAS-These handles are bent to fit the Ames Nursery Spades above described, and riveted. Price, $45 \mathrm{c} ; \$ 5.00$ per dozen.

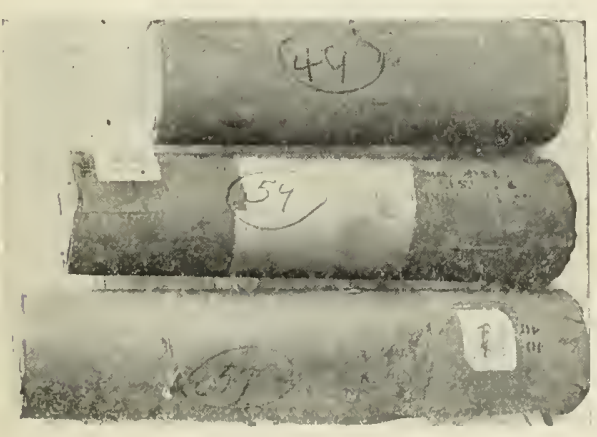

\section{BOX LINING PAPEI?}

This season we offer only KRAFT Paper. While it costs more per pound it is most economical because of its greater yardage. Put up in rolls of about 45 to $60 \mathrm{lbs}$, each; widths 30,36 and 40 inches. Price, per pound, $121 / 2 \mathrm{c}$. 


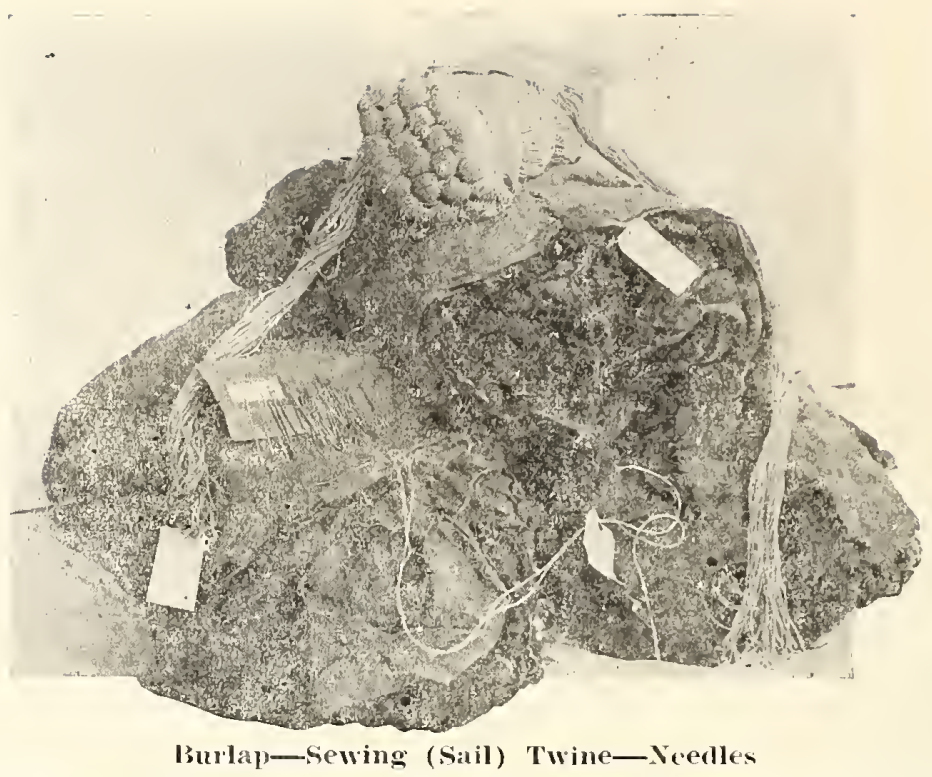

New Burlap is still "out of sight" in price and we are using selected Scrap. It does not contain fertilizer sacks, little pieces or rotten stock. It is put up in bundles of about one hundred pounds each. Price, per pound, F. O. B. here, $8 \frac{1}{2} \mathrm{c}$.

\section{(ORU) IGE, TWINES, ETC.}

$S$ ill high in price and going higher with deliveries uncertain. We placed oll? orders early and have the items in stock and hope to fill all orders promptly dinilg the sexson. ALL PRICES ARE SUBJECT TO MARKET CHANGES.

SAIL TIINE. For sewing burlap. Best quality Jute, 3-ply. Put up in skrins and 12-pound packages. Will sell any quantity desired. Price, per pound, $30 \mathrm{c}$.

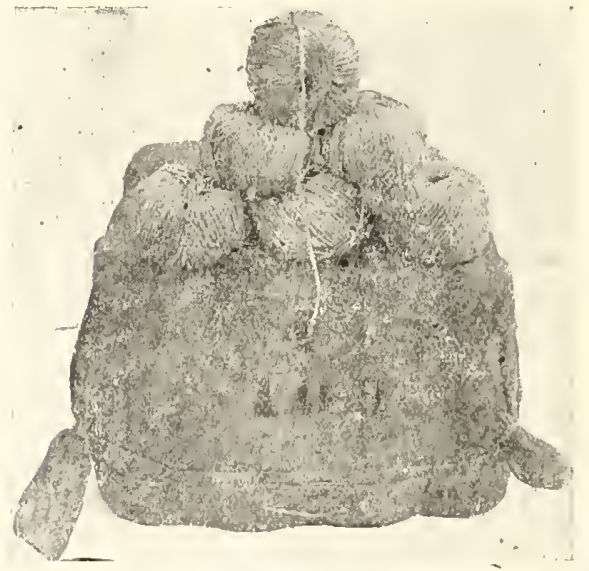

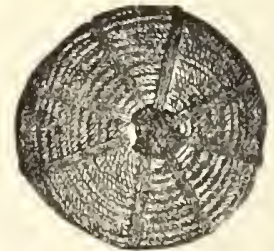

\section{FIVE-PIA BAIING CORD}

For heavy bales; breaking strength $240 \mathrm{lbs}$. A new type of baling cord made of Sisal and Jute mixed. On reels of about 50 lbs. Cannot break reels. Price, $24 \mathrm{c}$ per pound.

Bule of Wool Twine.

WOOL TWINE, Wour-Ply-For tying in bunches; in balls of about one pound each, packed in bales of about 130 Ibs. each. In bale lots, per pound, $20 \mathrm{c}$; less than bale lots at, per pound, $22 \mathrm{c}$.

WOOL, TWINE, Three-Ply-For bunching small fruits, roses, etc, this is plenty strong, and because of the greater yardage is cheaper than the foll-ply. Price, same as four-ply. 


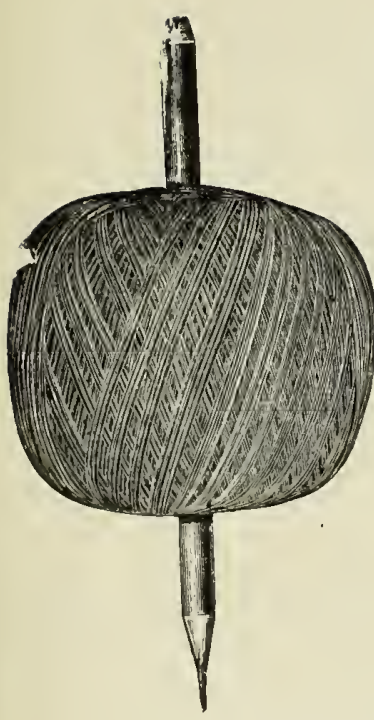

GRAFTING THREAD-Put up in balls and packed 20 balls to the box. A box of twenty balls will wrap about 40,000 average grafts.

Price per ball unwaxed.............\$0.10

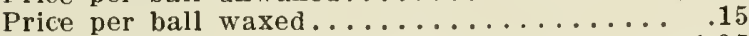

Price per box 20 balls unwaxed......... 1.35

Price per box 20 balls waxed........... 2.50

(If mailed, add $2 \mathrm{c}$ ball unwaxed and $5 \mathrm{c}$ ball waxed.)

The opposite illustration shows a ball of our grafting thread with a pencil run through the hole in the center.

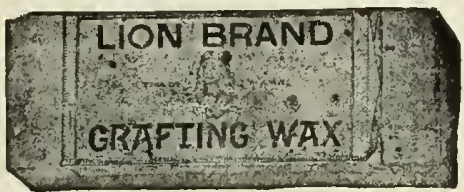

\section{GRAFTIN WAX}

For out-door use in top grafting fruit trees, etc. often you have use for a small quantity of Grafting Wax and do not want the bother of mixing it. This will just fill the bill.

$1 / 4$ lb. cake, postpaid $15 \mathrm{c}$

$1 / 2$ lb. cake, postpaid. $25 \mathrm{c}$

\section{BOX S'TR.AIS}

STEEL 13OX STRAPS-One-inch wide, 9 inches long, thin, soft steel, strong enough to hold the heaviest box. You can drive an ordinary nail through it without punching. About 2,800 pieces in 100 pounds. Less than 50 pounds, per lb., $12 \frac{1}{2} \mathrm{c} ; 50$ pound boxes, per $1 \mathrm{~b} ., 10 \frac{1 / 2}{\mathrm{c}}$.

\section{LABEIS}

IRON-WIRED-3 $3 \frac{1}{2}$ inches, plain, 1,000 to package; 90 cents per 1,000, by freight or express. In 5,000 lots, 85 cents per 1,000 ; in 10,000 lots, 80 cents per 1,000 .

COPPER-WIREI-_-Size same as above, add 25 cents per 1,000 .

LARGE "HFAD" LABELS-Size, $5 \times 1 \frac{1 / 8}{8}$ inches, copper-wired, blank, packed 200 in box. Price, per box, $80 \mathrm{c}$.

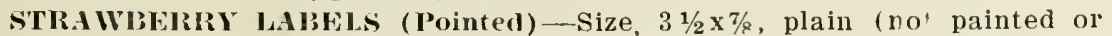
printed), packed 1,000 to box, slip under string on bunches of strawberry plants. Also used in small flower pots. Price, per box, $65 \mathrm{c}$.

FLORISTS' I'OT LAIBLAS (Pointed)-S'ze, $8 \mathrm{x}^{7} \%$, plain (not painted or printed), packed 500 to box. Price, per box, $\$ 1.65$.

IABEL,WIRE-Best Copper Wire, cut 7 inches long. Per lb., $\$ 1.00$.

LAIBEI,WIRE-Best l ron Wire, cut 7 inches long. Per lb., 60c.

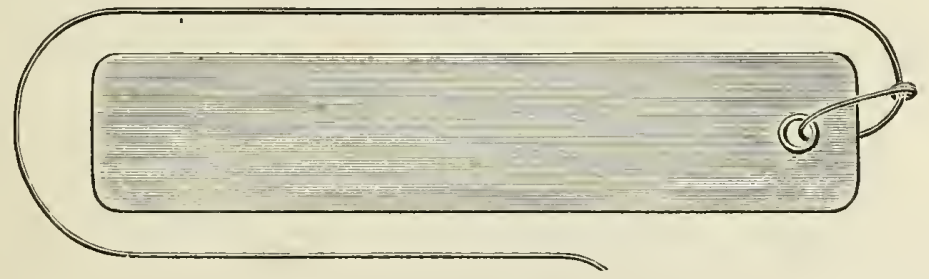

SHEET COPPHR TREE IAIBEL

An indestructible label for use on trees, shrubs, etc., as a PERMANENT MARKER. Directions: lay label on folded newspaper; write with very hard pencil or wire nail bearing on to indent metal. Give wire one turn around branch, securing end in loop. Remove to smaller branch every two years to prevent cutting wood. Price, postpaid, 25c per $10 ; \$ 2.00$ per 100 


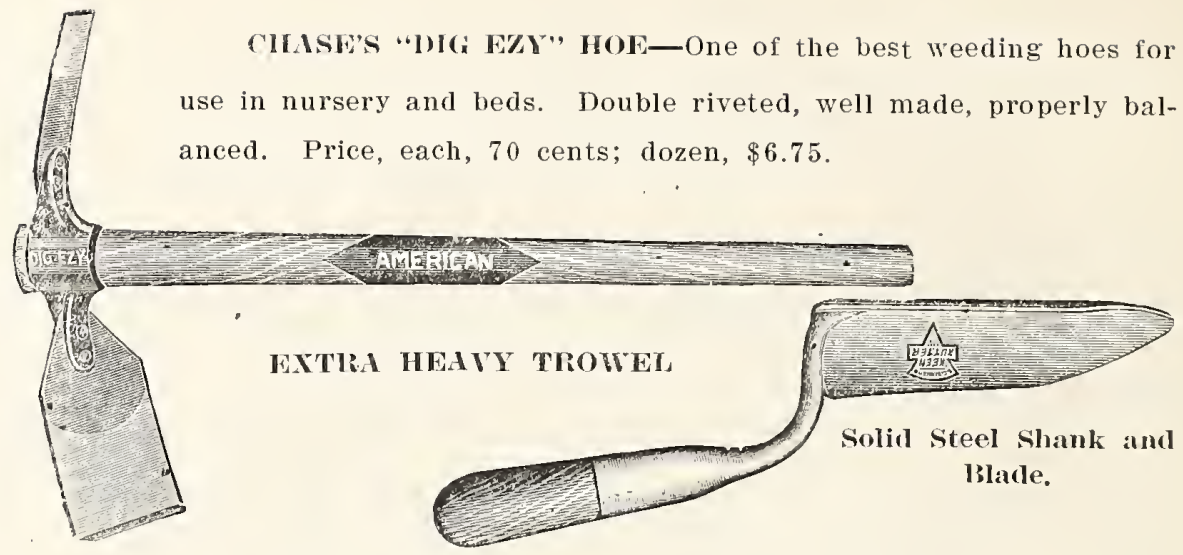

This is, we think, the best trowel made. Shank is solid steel. No rivets. Will last for yeals; 90 cents each, postpaid; 75 cents each with other goods, by freight or express.

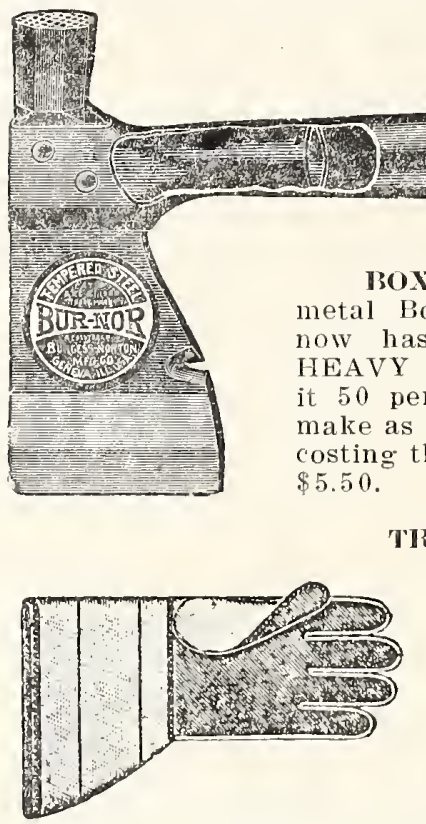

TRER GROWEIRS GLOVES

Here is a heavy Cotton Work Glove with palm and fingers faced with leather. Because of the high price of Mule Skin Mittens and the uncertain deliveries by the factory owing to scarcity of leather, we have added this heavy work glove to our line of Supplies. Our boys like them; warmer than all leather gloves or mittens; not as clumsy as mittens; will stand a good amount of hard work, and, price considered, are mighty good value. Per pair, postpaid, 50c; per dozen, $\$ 5.25$, postage extra. Half dozen at dozen rate.

\section{IRAFIA}

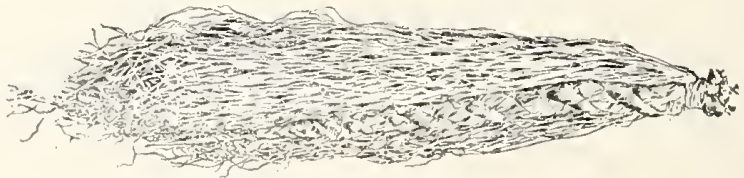

I:ATIA-We use the best Raffia we can buy, regardless of its cost, becanse, for nurserymen's use, the best is most economical.

Price, per pound, il lots under 10 pounds....................... $25 \mathrm{c}$

Price, per pound, in lots of 10 to 50 pounds........................... $231 / 2 \mathrm{c}$

Price, rel pound, in lots of 50 to 100 ponnds................... $22 \mathrm{c}$

Write for prices on full bales of about 220 pounds. F. O. B. hele. 


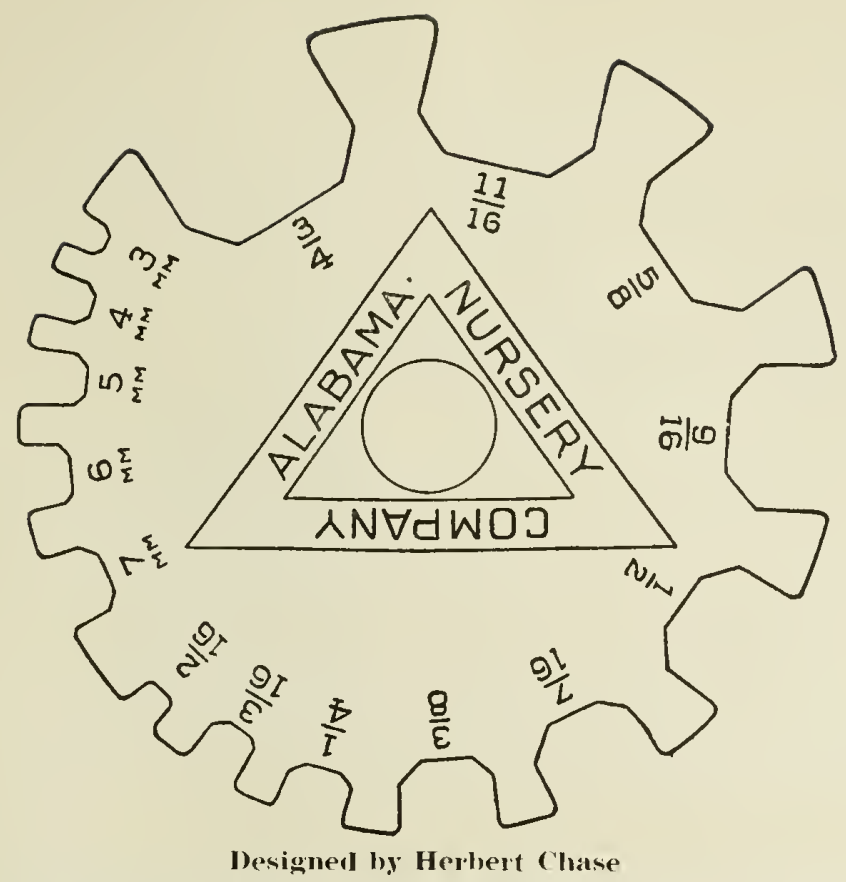

IMIROVED TREF GACGH-Price, any quantity, 50 cents each, postpaid. Made from "Sheradised" steel (a new process of treating steel); absotuely rustproof; both sides marked alike; always right side up; guaranteed accurate to within one-hundredth of an inch; indestructible; easy to read.

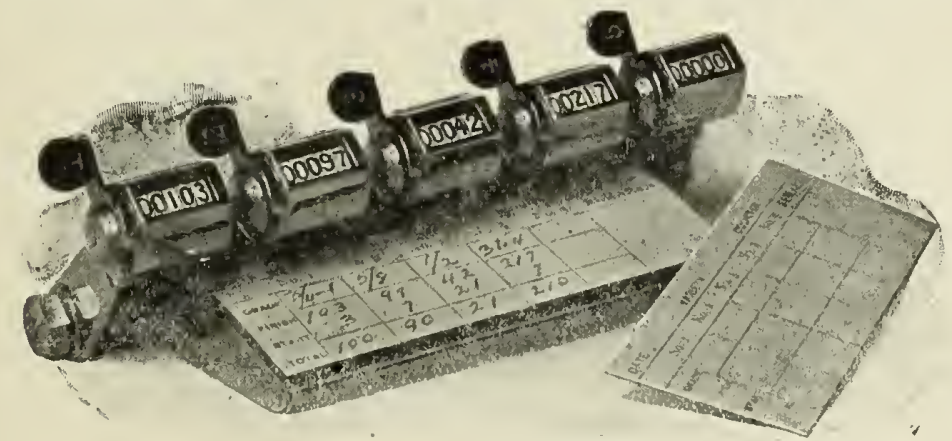

CHASH TREA COENTER

Still the Best Tree Commer on the Market

Designed by Robert Chase

These new machines are of the very latest type, extra heavy levers and springs, solid construction, heavily nickel plated. Guaranteed for three years. If for any reason a dial fails to work properly, send it to us to be put in ordel and returned without charge. The Chase Tree Counter is now used by most of the leading nurserymen.

Four-dial machine with 1,000 record cards, delivered

$\$ 18.00$ Five-dial machine with $\mathbf{1 , 0 0 0}$ record cards, delivered

Extra recerd rards, correct size, printed like cut, $75 \mathrm{c}$ for 500 ; per 1,000 postpaid

Accurate, quick, no guess work. Place in the hands of a good man, and as he passes down the row he presses the lever, which indicates the grade of the tree. When through with a variety, the dials show the total number of each grade in the block-the only method of taking a correct grade count in the field. One thousand record cards furnished with each machine. 


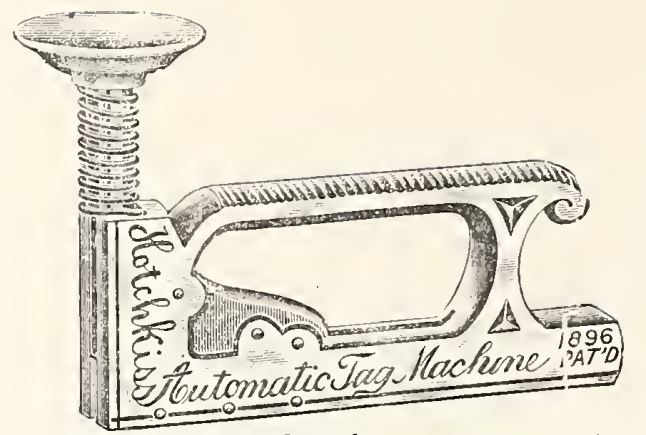

\section{IUTOMITIC TACKING: MACHINE}

For fastening tags or cards to tree boxes, cars, etc. The slickest little labor saver in our packing house. No bunting for tacks, no finger pricks, fumbling for hammer or lost motion. Just lay it on top of tag or card and tap the knob with plam of hand, a light tap; quick as lightning, will tag a box so quickly and easily that it is a joy to do it. Instead of round headed tacks this little machine au'omatically staples the tag or card in place. Guaranteed to work on any wcod. Money back if rot satisfactory; will ship on thirty days trial to any respcnsible nurseryman. Machine guaranteed against breakage for three years. Machine, each, $\$ 1.50$; staples, per box of $5,000, \$ 1.60$; postage extra.

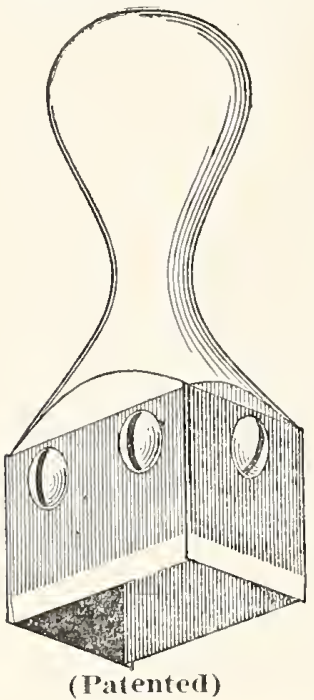

\section{THE JONES P.ATCH BUDDER}

Designed especially for budding Nut Trees or other subjects which cannot be propagated by ordinary methods. With this Budder, Pecans, Walnuts, Hickories, Chestnuts, Persimmons, etc., may be budded almost as eusily and rapidly as the more conmon fruit trees.

With careful work, one entirely inexperienced in propagation can get good results with this Budder right from the beginning, and with some practice can do rapid and very efficient work.

This little tool is now used by the U. S Governmert, many Experimental Stations and by all the leading propagators of Nut Trees, both North and South. Made of aluminum, machined perfectly true and nicely finished. The blades are made from safety razor blade steel, but of heavier stock. With full directions for budding Nut Trees, handling the buds, preparing waxed muslin, etc. Price, $\$ 1.50$ each, prepaid.

\section{BALED SPHAGMUY MOSS}

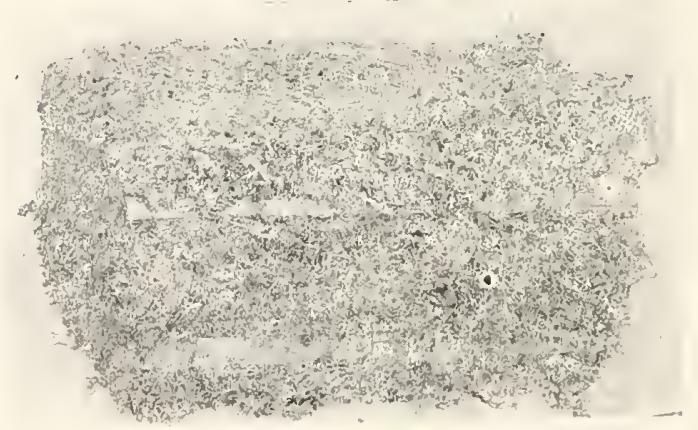

Fresh stock, bright and clean. Best quality Wisconsil Sphagnum, put up in wire bound bales size $24 \times 14 \times 18$ inches. For long distance shipment the bales should be wrapped in burlap. Price, per bale, $\$ 1.35$. If wanted wrapped in burlap add $15 \mathrm{c}$ per bale. The weight per bale is not guarnteed because it loses in weight constantly, due to evaporation.

\section{CHEMICALS FOR FUMICATING}

SODIMI (YANIDE (Merck \& Co.'s 97-99\%) Lumps, in original sealed tin packages, $1-1 b$. cans, $\$ 1.50$. Cyanide is excluded from the mails, but can be shipped by express or freight.

SULPHCRIC ACID (Specific Gravity 1.83). Large, glass stoppered bottles, securely packed in cases ready for shipment. 10-lb. bottle, $\$ 3.00$. Sulphuric Acicl cannot be shipped by express, but can be shipped by freight. 


\section{OFEICE SUPILIFS}

ORDER BOOlis-Your name and address printed, 100 orders to book, best quality, heavy glazed paper, latest form. Sample sheet free for the asking. Not less than $500 ; \$ 2.75$ for 500 (5 books) postage extra; $\$ 3.65$ per 1,000 ( 10 books), postage extra. Postage extra, 5c per book. Always give plain copy of firm name and address so that no mistake in printing will occur.

DELIVEIRY BOOKS-Bound in paper cover, ruled, showing name of customer, postoffice address, amount of order, how settled, etc. For 24 accounts, 50 cents per dozen, postpaid; for 72 accounts, 75 cents per dozen, postpaid; for 120 accounts, 85 cents per dozen, postpaid; for 168 accounts, $\$ 1.00$ per dozen, postpaid. Half dozen at dozen rates. Inexpensive and mighty handy.

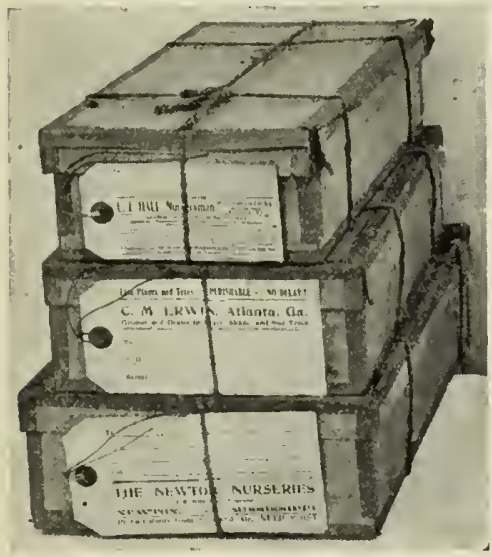

SHIPPING TAGS

Extra Quality, Waterproof, Brass-1Bound Eyelets

SHIPPING TAGS-Printed to order, strung ready for use. Three sizes. All have re-enforced eyelets.

\section{FXTRA QUALTY, WATERIROOF, BRASS-BOEND HYLETS}

(The best tag we know of)

Per 500

1,000

Size No. 5. $2 \frac{1}{2} \times 4 \frac{3}{4}$ inches, printed on one side $\$ 2.80$

Printed on two sides

3.80

$\$ 4.55$

Size No. 7. $27 / 8 \times 53 / 4$ inches, printed on one side

2.90

Printed on two sides

3.90

Size No. 8. $3 \frac{1}{8} \times 6 \frac{3}{8}$ inches, printed on one side

3.15

4.80

Printed on two sides................... 4.15

5.95

5.15

6.55

Note the large size (No, 8). This tag has plenty of room for address and Inspection Certificate on one side without crowding.

Always send copy showing how tags are to be printed. Samples on request.

\section{LETTERHEAIDS AND HNVELOPE} request.

Neatly designed, good quality paper, high grade printing, samples on

\section{LETTERHEAISS}

500 , full size, $81 \frac{1}{2} \times 11,20-1 b$. Bond, plain $\$ 2.50$

1000 , full size, $81 / 2 \times 11,20-1 \mathrm{~b}$. Bond plain 3.75

500 , full size, $81 \frac{1}{2} \times 11,20-1 b$. Bond, ruled 3.10

1000 , full size, $81 \frac{1}{2} \times 11,20-1 \mathrm{~b}$. Bond, ruled. 4.010

\section{EN VELOPES}

500 , size, $63 / 4, \mathrm{XXX}$

1000 , size $6 \%$, XXX

\section{PLATE BOOKS}

We have had some sperial Plate Books made up, rontaining varieties of Fruit Trees, Small Fruits, Shrubs, Shade Trees, Hedge Plants and Roses, that are all adapted to the general South. These books are bound in black leather, open at the top showing one plate at a time, containing 106 plates, with stubs for about 25 additional plates.

Price, each book.................................. $\$ 5.4$ 


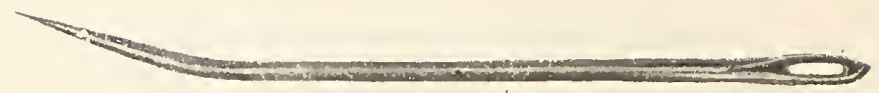

Best grade, five-inch, large stiff shaft, wide flat shank, sharp point and large eye. Per dozen, $40 \mathrm{c}$.

Medimm grade, five and a quarter inch, light and flimsy, not much in price or quality. Per dozen, $25 \mathrm{c}$. 


\section{GRADES}

We grade liberally by caliper and height. When both are specified, caliper measure governs, but we are careful to see that stock is uniform throughout. Our rule is: "WHEN IN DOUBT, PUT IN THE LOWER GRADE."

All stock is graded and bunched in our storage houses, where we have water in abundance. Stock is handled from field to these buildings under large tarpaulins and roots kept moist until boxed.

\section{LIABILITY AND CLAIMS}

We are not liable for injury to stock from frost, hail, fire, or other causes beyond our control, and book all orders with this understanding. While we use every means at our command to secure prompt delivery, WE ARE NOT LIABLE FOR DELAYS IN TRANSIT; OUR RESPONSIBILITY ENDS UPON DELIVERY IN GOOD ORDER TO RAILWAY COMPANY. Remedy for loss must lie between the buyer and the railway company, but we will gladly render all the aid we can. Any other claims must be made within five days after arrival of goods.

\section{NON-WARRANTY CLAUSE}

We give no warranty, express or implied, as to description, quality, productiveness, or any other matter of any nursery stock, seeds, bulbs or plants we sell.

\section{SUBSTITUTION}

We do not substitute unless instructed to do so, AND THEN LABEL TRUE TO NAME.

\section{COIE WORDS-TEIEGRAPHIC ORDERS}

When more than one grade of fruit trees is listed, a code word is used. Much expense can be saved in telegraphic orders by using these code words in connection with Nurserymen's Telegraphic Code, a copy of which will be mailed upon request.

\section{BOXING}

Charges as low as possible for well-made boxes, paper-lined:

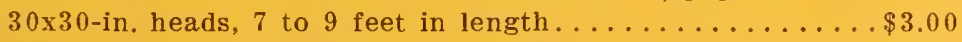

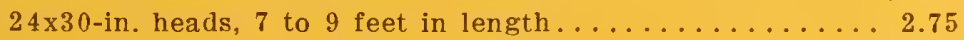

$24 \times 24$-in. heads, 7 to 9 feet in length................. 20

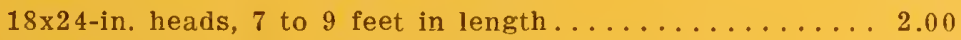

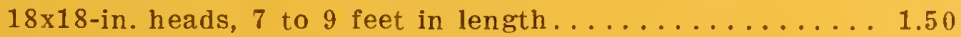

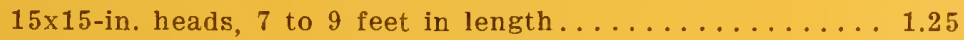

$12 \times 12$-in. heads, 7 to 9 feet in length............ 1.00

On orders for roses, small fruits, etc., we can frequently use drygoods lowest possible charges.

cases or shoe boxes at lower cost, and shall endeavor at all times to make

Bales, 25 cents to $\$ 1.50$, according to size.

No packing charge if loaded in bulk car. 


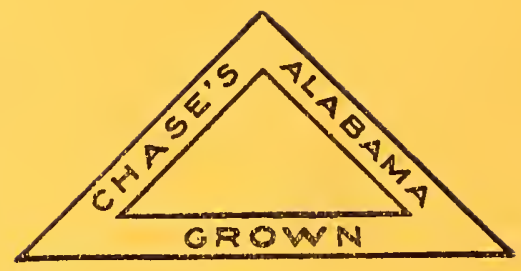

